\title{
Growth Hormone Gene Polymorphism and its Relation to Quail Growth and Carcass
}

\author{
Fatma İlhan,a,* \\ ${ }^{1}$ Department of Animal Science, Faculty of Agriculture, Selçuk University, 42130 Konya, Turkey \\ ${ }^{*}$ Corresponding author

\begin{tabular}{l|l}
\hline A R T I C L E I N F O & A B S T R A C T \\
\hline Research Article & $\begin{array}{l}\text { In this study, it was aimed to determine the polymorphism of GH (growth hormone) gene in } \\
\text { Japanese quails and the relationships between these genes and body weight and carcass traits. 3 } \\
\text { genotypes (AA, AB and BB), 2 (A and B) alleles were detected by cutting the GH intron } 1 \text { region } \\
\text { with restriction enzyme MspI. As a result of variance analysis, it was determined that the hatching } \\
\text { weights of the animals with B allele and liver weights were higher. Thus, it is seen that GH gene } \\
\text { and PCR-RFLP technique can be used in breeding studies. }\end{array}$ \\
$\begin{array}{l}\text { Received : 23/12/2020 } \\
\text { Accepted : } 02 / 08 / 2021\end{array}$
\end{tabular}

Keywords:

Growth hormone

Quail

PCR-RFLP

MspI

Gene

fatmailhan@selcuk.edu.tr

(D) https://orcid.org/0000-0002-9248-2056|

(c) () (9) This work is licensed under Creative Commons Attribution 4.0 International License

\section{Introduction}

Due to the fact that quail products are a quality food source are easy to grow and are a suitable source to meet the increasing protein need, interest in this branch of production is increasing day by day. For this reason, breeding of quail becomes important and in this context, the importance of genetic studies is increasing. Considering the yield of meat and eggs in quails, Growth hormone $(\mathrm{GH})$ gene should be emphasized. While these genes have been studied quite a lot in chickens, there is not enough study in quail. To reveal the polymorphism of these genes and their relations with yield is important for the production of quail.

Growth hormone is a polypeptide produced and secreted from the anterior lobe of the pituitary gland. This hormone is a hormone that affects properties such as growth, body condition, egg production, and immunity. Therefore, this hormone is a candidate gene in yield studies in poultry (Nie et al., 2005).

$\mathrm{GH}$ performs its function by stimulating processes such as growth and fat metabolism with appropriate receptors on the wall of the target cells (Garrett et al., 2008).

\section{Material and Methods}

Research, it was carried out with 1 day old 84 quail purchased from a commercial firm. The birds with suitable body weights were attached to the quail growth cages by placing the wing number without sex determination. A standard diet was provided ad libitum during the 0-6 week age.

The body weights of the animals were weighed individually at the time of hatching and for a period of 6 weeks. Body weight gains calculated for each week. Following the last weighing, animals were slaughtered and cleaned to determine if genotypes have any effect on carcass, liver and abdominal fat weights. The blood was taken from jugular vein into $2 \mathrm{ml}$ vacutainer tube containing EDTA as anticoagulant. Blood brought to the laboratory and kept until DNA isolation at $-4{ }^{\circ} \mathrm{C}$. Genomic DNA was isolated from blood samples according to the method describe in Miller et al. (1988). The concentration and purification of genomic DNA was quantified with a NanoDrop ND-1000 spectrophotometer, and $20 \mathrm{ng}$ of genomic DNA was used for the PCR. Using the primers reported by Johari et al. (2013) for PCR processing of the $\mathrm{GH}$ gene, the PCR conditions were adapted to the 
laboratory where the investigation will be conducted. The $\mathrm{GH}$ primer sequences were

\section{F:5'-ATCCCCAGGCAAACATCCTC-3';}

R:5'-CCTCGACATCCAGCTCACAT-3'

with size product $776 \mathrm{bp}$. PCR was performed using the PCR Master Mix (Thermo Scientific, fermentas). The kit of master mix consisted of $2.5 \mu \mathrm{L}$ of $10 \mathrm{x}$ PCR buffer, 2 $\mathrm{mM}$ of $\mathrm{MgCl} 2$ and $2 \mathrm{mM}$ dNTPs (each). The PCR reactions were carried out in a total volume of $25 \mu \mathrm{l}$ containing the following reaction mixture: $20 \mathrm{ng}$ of purified quail DNA, $15 \mu \mathrm{l}$ of the master mix and $0.5 \mu \mathrm{l}$ of each primer. The following amplification profile was used: initial denaturation at $94^{\circ} \mathrm{C}$ for $5 \mathrm{~min}, 35$ cycles at $94^{\circ} \mathrm{C}$ for $30 \mathrm{~s}$, annealing at $60^{\circ} \mathrm{C}$ for $30 \mathrm{~s}$ and extension at $72^{\circ} \mathrm{C}$ for $1 \mathrm{~min}$, followed by a final extension step at $72^{\circ} \mathrm{C}$ for 10 min. PCR products were digested with restriction enzyme $M s p \mathrm{I}$ at $37^{\circ} \mathrm{C}$ for overnight. The digestion mixtures were tested by electrophoresis on $2.5 \%$ ethidium bromide stained agarose gels in $0.5 x$ TE buffer. The gels were photographed under UV light and the DNA bands were evaluation.

PopGene 3.1 (Yeh et al., 1997) was used for allele and genotype frequencies. The data used to compare the effect of polymorphism of GH gene on body weight and carcass traits of quails were tested with the use of anova at SPSS (Kinnear and Gray, 1994). The genetic effect were analysed using the following model:

$$
\mathrm{Y}_{\mathrm{ij}}=\mu+\mathrm{G}_{\mathrm{i}}+\mathrm{e}_{\mathrm{ij}}
$$

$Y_{i j}$ is the observed value of dependent variable, $\mu$ is mean, $G_{i}$ is the effect owing to genotype $\mathrm{GH}$ and $\mathrm{e}_{\mathrm{ij}}$ is the random residual error.

\section{Results}

In the study, a $776 \mathrm{bp}$ fragment was amplified in the $\mathrm{GH}$ locus. We were determinate three genotypes result of restriction by $M s p$ I enzyme; AA (539, 237 bp), BB (776 bp) and $\mathrm{AB}(776,539,237 \mathrm{bp})$ (Figure 1 and 2). Alleles found in this study were similar to those previously identified and reported by Johari et al. (2013).

The intron-I of the GH (Forward and Reverse) were amplified using PCR-RFLP method.

Allele A obtained from the digestion of GH with $M s p$ I was more frequent in the quails. Genotype ab was more frequent. The HW test showed that the studied fit the theoretical proportions $(\mathrm{P}>0.05)$ (Table 1).

When we look at the weekly live weight results, it was observed that there was no difference between the genotypes other than the hatching weight. The hatching weight was higher in animals with $\mathrm{B}$ allele $(\mathrm{P}<0.05)$.

When the carcass results were examined, it was found that the liver weight was higher in animals with $\mathrm{B}$ allele $(\mathrm{P}<0.05)$.

\section{Discussion}

GH has been found to be associated with many yield parameters and diseases. GH alleles identified were linked to egg production, resistance to Marek's disease (MD) and avian leukosis (ALV) in the chicken (Kuhnlein et al., 1997; Makhsous et al., 2013). In other PCR-RFLP studies on this gene, it was determined that some alleles may be linked to laying performance (Mou et al., 1995).

In this study, it is aimed to investigate whether there is a relationship between polymorphism in the quail GH gene region and live weight and carcass results. As a result of cutting the GH gene region with MspI enzyme, it was determined that the A allele was at a higher frequency and the ab genotype was at a higher frequency than other genotypes and the population was in balance. According to the weekly live weight results, only a significant correlation was found between the hatching weight and genotypes $(\mathrm{P}<0.05)$.

It was observed that the hatching weights of animals with B allele were high. Studies have also found a relationship between live weight and genotypes (Nasirifar et al., 2018). It was determined from the carcass results that there was a relationship between liver weight and genotypes, and animals with $\mathrm{B}$ allele were high in liver weight $(\mathrm{P}<0.05)$.

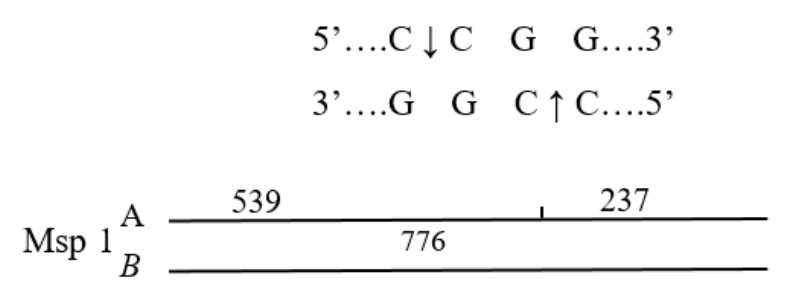

Figure 1. GH gene region $M s p$ I enzyme restriction model

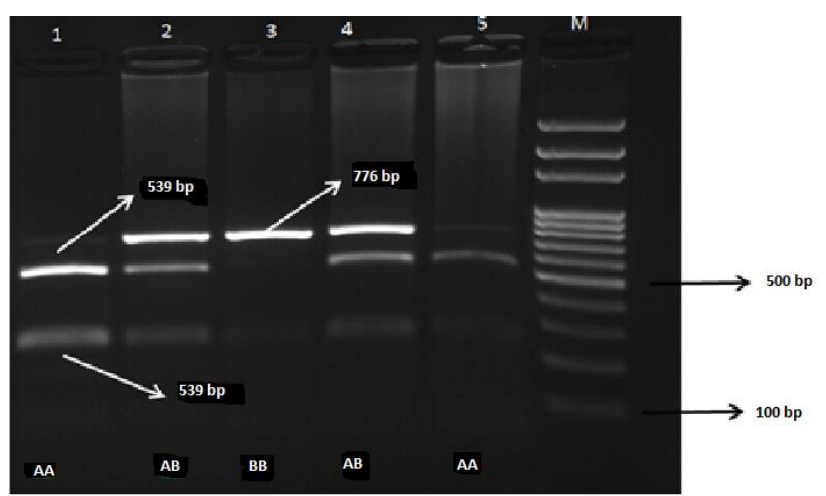

Figure 2. DNA electrophoretic pattern obtained after digestion of PCR amplified GH gene products with MspI, M: 100 bp ladder marker.

\section{Conclusion}

As a result, quail has recently gained importance as an alternative protein source. For this reason, quail farming is increasing day by day. The use of productive animals in breeding always increases the profit of the enterprise. Therefore, since the growth hormone $(\mathrm{GH})$ gene is a gene directly related to yield, it is a gene that should be emphasized in breeding studies. As obtained in this study, breeding studies can be carried out by considering the relationship between hatching weight and genotypes. With PCR-RFLP studies with more animals, it is likely that there will be relationships between this gene and other yield characteristics. For this reason, PCR-RFLP method appears to be a feasible method for determining $\mathrm{GH}$ gene polymorphism and its relationship with live weight in quail. 
Table 1. The allele and genotype frequencies for GH gene as restriction by $M s p \mathrm{I}$.

\begin{tabular}{|c|c|c|c|c|c|}
\hline Genotype frequencies & \multicolumn{4}{|c|}{ Allele frequencies } & \multirow{2}{*}{ Chi-Square $\chi^{2}$} \\
\hline $\mathrm{AA}(\%)$ & $\mathrm{AB}(\%)$ & $\overline{\mathrm{BB}(\%)}$ & $\mathrm{A}$ & $\mathrm{B}$ & \\
\hline 39.69 & 46.62 & 13.69 & 0.63 & 0.37 & 2.43 \\
\hline
\end{tabular}

Table 2. Weekly body weights of quails as affected by polymorphism for GH gene as restriction by $M s p \mathrm{I}$.

\begin{tabular}{l|ccc}
\hline \multicolumn{1}{c|}{ Weeks } & AA & AB & BB \\
\hline Hatching & $7.76 \pm 0.17^{\mathrm{b}}$ & $8.53 \pm 0.19^{\mathrm{ab}}$ & $8.55 \pm 0.21^{\mathrm{a}}$ \\
1 & $16.53 \pm 0.83$ & $18.26 \pm 0.91$ & $15.5 \pm 2.10$ \\
2 & $31.27 \pm 2.81$ & $33.09 \pm 1.56$ & $34.25 \pm 3.45$ \\
3 & $55.67 \pm 3.42$ & $58.91 \pm 2.44$ & $58.00 \pm 6.75$ \\
4 & $86.53 \pm 5.13$ & $92.13 \pm 3.44$ & $91.25 \pm 11.03$ \\
5 & $122.13 \pm 13.00$ & $123.35 \pm 3.55$ & $114.75 \pm 4.67$ \\
6 & $159.00 \pm 4.67$ & $165.00 \pm 3.06$ & $160.12 \pm 8.13$ \\
\hline
\end{tabular}

${ }^{*} \mathrm{P}<0.05$ Different small letters within each line refer to a significant difference at values are Mean \pm SE.

Table 3. Carcass traits of quails as affected by polymorphism for GH gene as restriction by $M s p$ I.

\begin{tabular}{l|ccc}
\hline \multicolumn{1}{c|}{ Carcass traits } & AA & AB & BB \\
\hline Carcass weight & $95.30 \pm 3.99$ & $100.73 \pm 2.36$ & $95.74 \pm 6.08$ \\
Liver weight & $3.89 \pm 0.18^{\mathrm{b}}$ & $4.65 \pm 0.17^{\mathrm{a}}$ & $4.22 \pm 0.32^{\mathrm{ab}}$ \\
Abdominal fat weight & $0.43 \pm 0.15$ & $0.56 \pm 0.09$ & $0.35 \pm 0.15$ \\
\hline
\end{tabular}

${ }^{*} \mathrm{P}<0.05$ Different small letters within each line refer to a significant difference at values are Mean $\pm \mathrm{SE}$.

\section{Acknowledgements}

We thank Selçuk University, The Scientific Research Projects Coordinating Office (project no: 18401126; principal investigator: Fatma İlhan).

\section{References}

Garrett AJ, Rincon G, Medrano JF, Elzo MA, Silver GA, Thomas M G. 2008. Promoter region of the bovine growth hormone receptor gene: Single nucleotide polymorphism discovery in cattle and association with performance in Brangus bulls. Journal of Animal Science, 86(12): 3315-3323. DOI: 10.2527/jas.2008-0990.

Johari S, Setiati N, Sidadolog JHP, Hartatik T, Yuwanta T. 2013. The gene effect of growth hormone on body weigth and egg production in divergent selection for five generation of japanese quail (Coturnix coturnix japonica). International Journal of Poultry Science, 12 (8): 489-494. DOI: 10.3923/ijps.2013.489.494.

Kinnear PR, Gray CD. 1994. SPSS for Windows. Department of Psychology University of Aberdeen, UK.

Kuhnlein U, Ni L, Zadworny D, Weigend S, Gavora JS, Fairfull W. 1997. DNA polymorphisms in the chicken growth hormone gene: response to selection for disease resistance and association with egg production. Animal Genetics, 28(2): 116-123. DOI: 10.1111/j.1365-2052.1997.00076.x.
Makhsous SG, Mirhoseini SZ, Zamiri MJ, Niazi A. 2013. Polymorphisms of growth hormone gene in a native chicken population: association with egg production. Bulletin of the Veterinary Institute in Pulawy, 57(1): 73-77. DOI: 10.2478/bvip-2013-0014.

Miller SA, Dykes DD, Polesky HF. 1988. A simple salting out procedure for extracting DNA from human nucleated cells. Nucleic Acids Research, 16 (3): 1215. DOI: 10.1093/nar/ 16.3.1215.

Mou L, Liu N, Zadworny D, Chalifour L, Kuhnlein U. 1995. Presence of an additional PstI fragment in intron 1 of the chicken growth hormone-encoding gene. Gene, 160(2): 313314. DOI:10.1016/0378-1119(95)96895-8

Nasirifar E, Talebi M, Esmailizadeh A, Askari N, Sohrabi SS, Moradian H. 2018. Genetic variability in growth hormone gene and association between restriction fragment length polymorphisms (RFLP) patterns and quantitative variation of live weight, carcass, behaviour, heterophil and lymphocyte traits in Japanese quails. Iranian Journal of Applied Animal Science, 8(1): 147-152.

Nie Q, Lei M, Ouyang J, Zeng H, Yang G, Zhang X. 2005. Identification and characterization of single nucleotide polymorphisms in 12 chicken growth-correlated genes by denaturing high performance liquid chromatography. Genetics Selection Evolution, 37(4): 1-22. DOI: 10.1186/ 1297-9686-37-4-339.

Yeh FC, Yang RC, Boyle TBJ, Ye ZH, Alberta MJX Uo (Ed.), POPGENE the User-Friendly shareware for population genetic analysis (1997). 